\title{
Multidisciplinary Approach for a Solution to Floods in Sampathé District (Thiès-Est, Senegal)
}

\author{
Mouhamadou Moustapha Mbacké Ndour ${ }^{1 *}$, Alassane Thiam1, Bakary Fall², Ibrahima Seye ${ }^{3}$ \\ ${ }^{1}$ Unité de Formation et de Recherches-Sciences de l'Ingénieur, Université of Thiès, Thiès, Sénégal \\ ${ }^{2}$ Centre de Suivi Ecologique, Dakar, Sénégal \\ ${ }^{3}$ Grande Côte Opération Sa, Dakar, Sénégal \\ Email: moustapha.ndour@univ-Thiès.sn
}

How to cite this paper: Ndour, M.M.M., Thiam, A., Fall, B. and Seye, I. (2020) Multidisciplinary Approach for a Solution to Floods in Sampathé District (Thiès-Est, Senegal). Journal of Geographic Information System, 12, 663-682.

https://doi.org/10.4236/jgis.2020.126038

Received: August 27, 2020

Accepted: December 7, 2020

Published: December 10, 2020

Copyright $\odot 2020$ by author(s) and Scientific Research Publishing Inc. This work is licensed under the Creative Commons Attribution International License (CC BY 4.0).

http://creativecommons.org/licenses/by/4.0/ (c) (i) Open Access

\begin{abstract}
In recent years (2003), Senegal has been confronted with many urban flooding problems that have become recurrent due to the configuration of its settlement. This is due to galloping population growth, climate change and a lack of planning and rainwater drainage networks. To fix these phenomena, Senegalese government has initiated rainwater drainage programs. In the city of Thiès, particularly in Sampathé district, flooding problem is a reality that is observed during every winter period. It is within this framework that we have proposed a project for the design and dimensioning of a rainwater evacuation network in Sampathé. The network will be integrated into a Geographic Information System for efficient management of project. This study involved identifying flood zones, determining geotechnical characteristics of the soil, and exploiting rainfall data in order to propose a storm water drainage network that will be integrated into a database management system. Thus, we carried out topographical and geotechnical studies, then designed and dimensioned the drainage network, and finally set up a geographic information system. At the end of this project, we designed a sewerage network consisting of two primary pipelines, four secondary pipelines, one tertiary pipeline, ninety-two manholes and a retention basin. To manage the network, we set up a geographic information system to geolocate various elements for rapid intervention in the field in event of a problem, make requests, generate thematic maps, and perform spatial analyses for good decision-making.
\end{abstract}

\section{Keywords}

Flood, Flooding, Sewerage Network, Topographic Surveys, Geographic Information System, Sampathé 


\section{Introduction}

Senegal, like many developing countries, a known galloping urbanization [1]. The nature of the growth of cities and the economic and political upheavals that accompany them, cause a number of tensions and increase environmental problems [2] [3] [4] categorized these consequences into physical and social impacts. Physical impacts cover both deaths and injuries to people, damage to buildings, infrastructure, the natural or agricultural environment (physiological impacts, impact on buildings and the environment) [5] [6] [7]. Social impacts cover effects of floods at psychological, demographic, economic, political and cultural levels [8] [9] [10] [11] [12] and [13].

Flood damage depends on land use policies. This damage will also result from climatic upheavals themselves, such as changes in frequency of tropical cyclones (Bates et al. 2008) [14]. Significant damage resulting from these floods is strongly observed on people and their property (50,300 people affected in 2003 and 200,000 people in 2004 and more than 20,000 houses collapsed or flooded) (DPC-PNUD, 2008) [15]. The 2009 floods cost around 42 billion CFA francs, including 24 billion in damage and 20 billion in losses. Most significant damage concerns housing (61\%), transport monitoring (11\%) and health (10\%). As for the losses, they mainly concern trade (23\%, in particular informal trade), housing (18\%), community urban infrastructures (18\%), energy (17\%) and transport (16\%) (République du Senegal, 2010) [16]. Today, several actions are being undertaken by State of Senegal through the Ten-Year Flood Control Plan. Despite these efforts, flooding problems remain in Senegal.

This is how Thiès city, especially Sampathé district, is not immune to flooding. This district is characterized by a mode of urbanization which no longer allows the natural drainage of rainwater towards drainage box, dimensions of which have become insufficient to collect and ensure effective drainage of rainwater. The irregular occupations of space and the lack of a storm sewer network are the main causes of flooding in neighborhood. This unbridled urbanization and poor management of household waste are the causes of poor drainage of wastewater and rain. This pushes the municipal authorities to always undertake cleaning activities of the pipes and culvert in the neighborhood. However, flooding still persists in the area.

To provide a lasting solution to these recurring floods, it is important to have information on geomorphology, type of development, characteristics of the soils, climatic parameters and the socio-demographic characteristics of populations.

Admittedly, there are numerous studies on the issue of flooding in Senegal in Dakar (Thiam, 2011) [17], then in Saint-Louis (Thiam, 2020) [18], but no specific studies on Sampathé area. This is what justifies the research project.

Our objective is therefore to offer a multidisciplinary approach to provide a solution to the floods in the Sampathé district.

This study is based on a multidisciplinary approach, combining topographic analysis, pedology, Geographic Information System (GIS) and geotechnics, in 
order to understand the multidimensional nature of flooding phenomenon in Sampathé district.

\section{Methodology}

\subsection{Presentation of the Study Area}

Situated at $70 \mathrm{~km}$ from Dakar, Thiès region is one of the 14 administrative regions of Senegal [19]. It is located in the west of the country, in a ring around Cape Verde peninsula. It covers an area of $6601 \mathrm{~km}^{2}$, or $3.4 \%$ of national territory and is limited to the north by Louga region, to south by Fatick region, to east by Diourbel and Fatick regions and to west by Dakar region and Atlantic Ocean (Figure 1). According to 2019 projections from National Agency for Statistics and Demography (ANSD), its total population amounts to 2.105 .707 inhabitants, equivalent to $13 \%$ of national population and the second most populous regions in Senegal after Dakar. While its population in 2002 was only 1.331.916, it is easy to notice that demography of Thiès region has almost doubled in 17 years. Geologically, Thiès region is in Senegalese-Mauritanian sedimentary basin. Land is made up of plateaus, depressions and hills: Thiès plateau that culminates at $137 \mathrm{~m}$ of altitude [20].

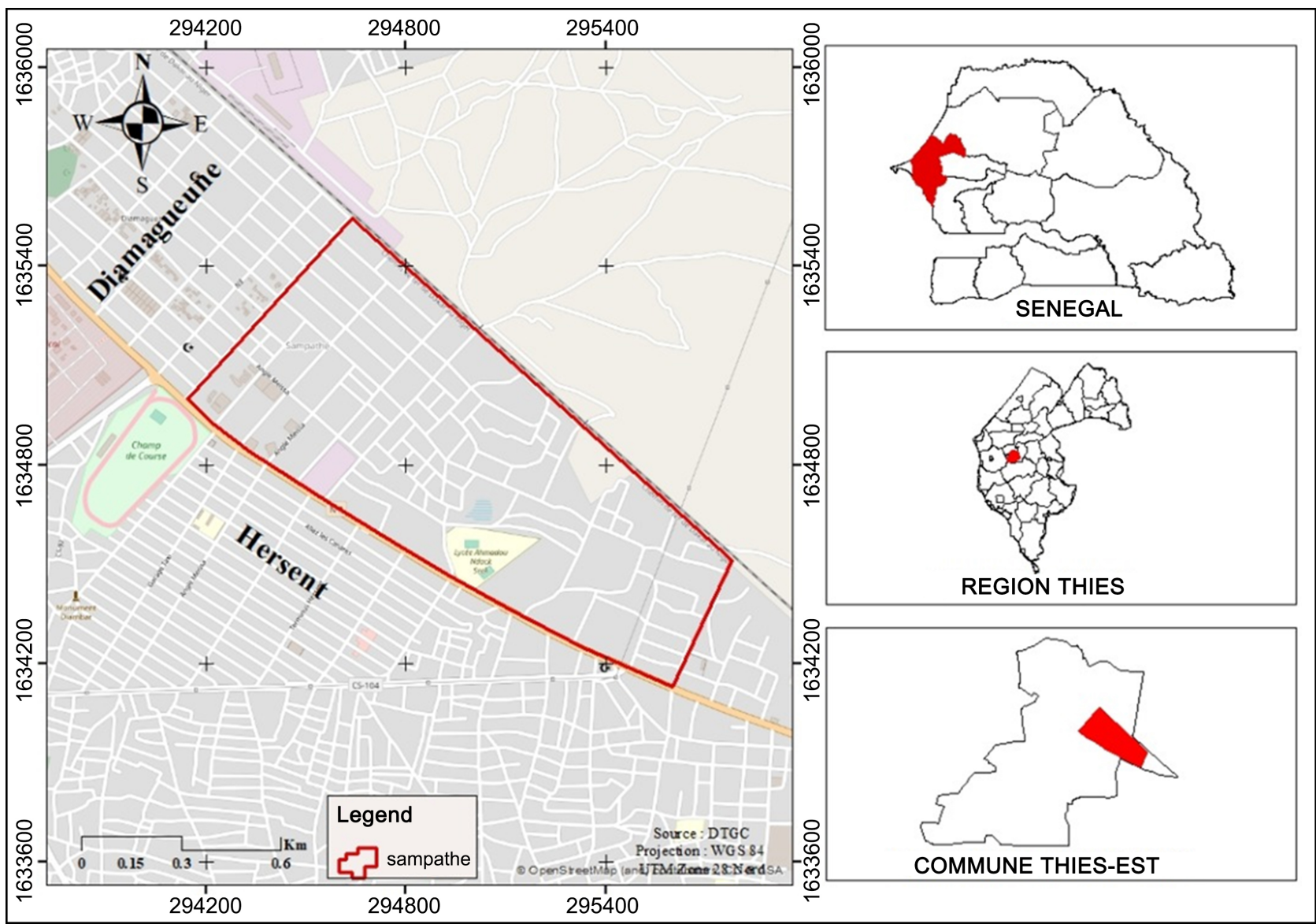

Figure 1. Geographical location of the Sampathé district. 
The study area is located in the municipality of Thiès-Est, precisely in Sampathé district with an area of 78.23 ha (Figure 2). It is exactly located in the north of Thiès racecourse towards Khombole (Figure 2).

\subsection{Topography}

As part of topographic studies, a pre-reconnaissance study is carried out with simulations on Google Earth Pro to get an overview of relief of the study area. This operation showed an inclination of relief from north-west to south-east with an altitude variation of 73 to $58 \mathrm{~m}$ (Figure 3) and also an average slope oriented from south-west towards northeast with altitudes varying between 71 and $61 \mathrm{~m}$ (Figure 4).

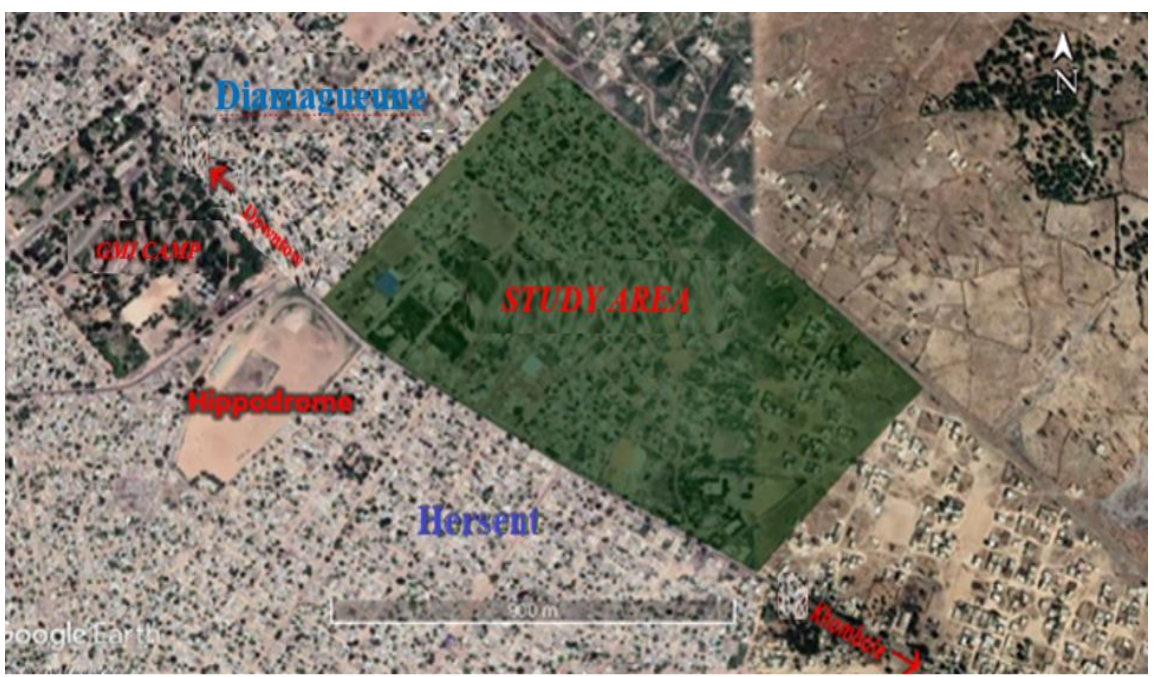

Figure 2. Location of study area (Google Earth).

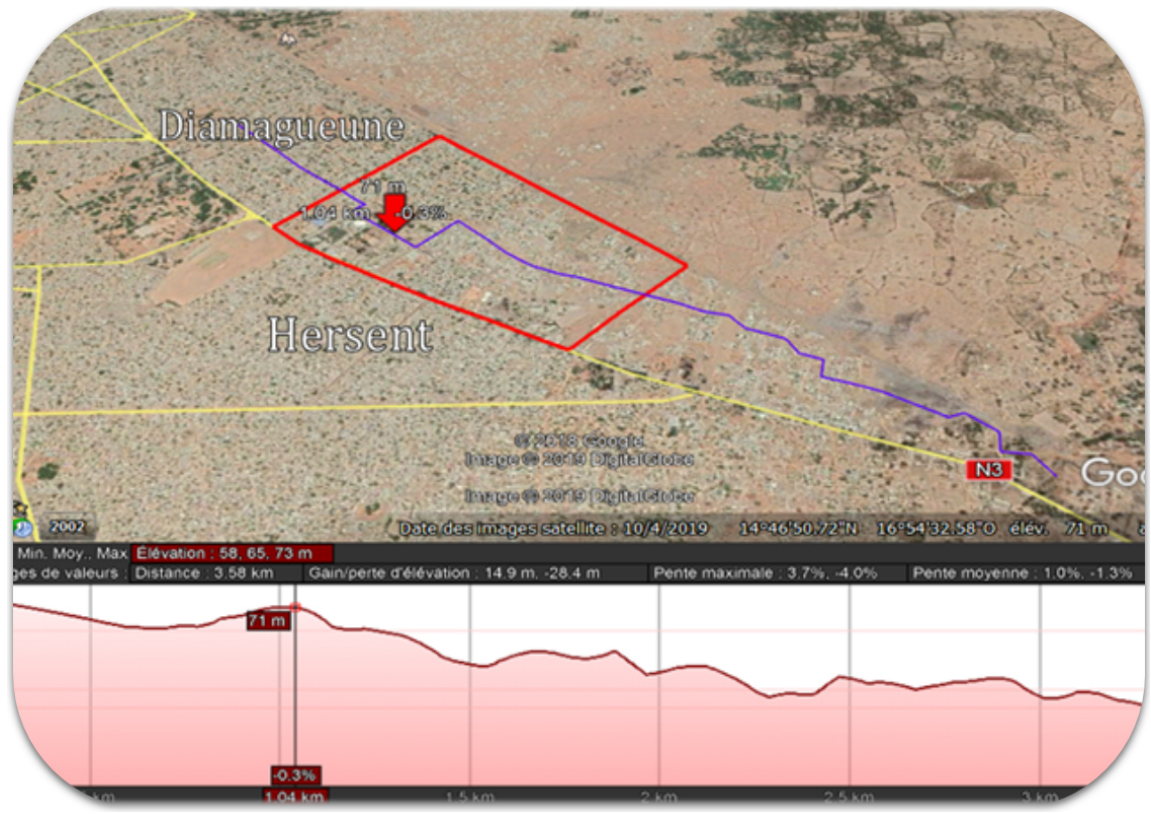

Figure 3. North-west/south-east elevation profile. 


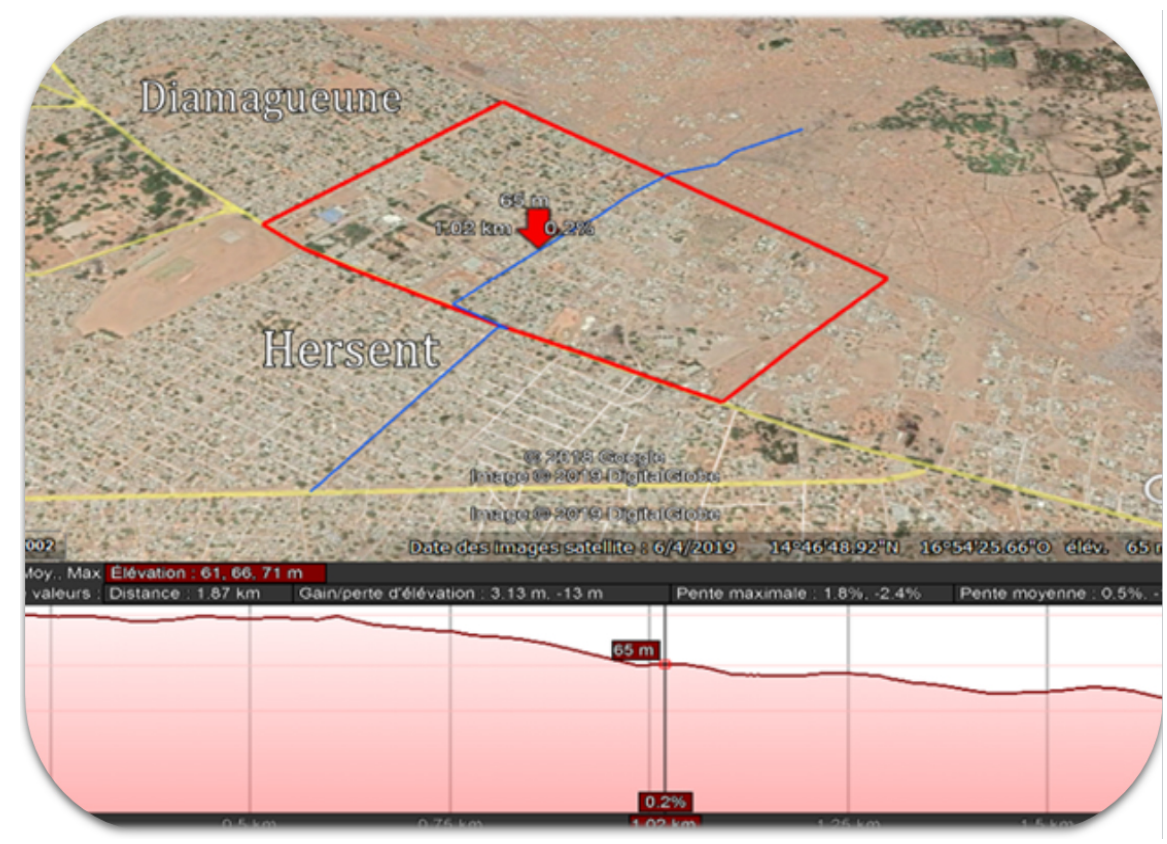

Figure 4. Southwest/Northeast elevation profile.

A topographical inventory was also carried out with Leica GS14 differential GPS and Leica TS06 Plus total station. Combination of two devices is justified by multipath phenomena, which are very penalizing because waves emitted by satellites do not necessarily reach receiver in a straight line [21]. Thus a loss of differential GPS signal is noted in highly urbanized study area (Sampathe). Use of GPS is not recommended, hence use of total station to overcome this obstacle. This work made it possible to identify geographical position of wastewater manholes, installation of electrical and telephone networks, existing pipelines as well as heads of islands; this is to know real configuration of land that must be taken into account for the layout of network framework.

High precision elevation data is essential in a remediation project. Thus, cholesky dual tracking method is used with a Zeiss Ni2 level. It consists of reading three wires (leveler and stadimetrics) on each path at each sighting, i.e. twelve readings per station [16]. And to make obtained data more precise, a closed path which consists mainly of closing at a point whose altitude is known [22] is carried out around perimeter of studied area.

The sight of points from topographic studies made it possible to determine digital model of the natural field to identify flood zones and water receptacles. Data from cholesky leveling allowed calculation of Kirby hydrological similarity index called the topographic index. A calculation of topographic index (TI) is made with ArcGIS software.

The topographic index is obtained by the formula

$$
\mathrm{IT}=\frac{\ln \alpha}{\ln \beta}
$$

With: 
IT: topographic index,

$\alpha$ : accumulation flow,

$\beta$ : slope, "Fill" to create a continuous relief surface, Direction flow to generate a raster of flow directions and Accumulation flow to have surface drained at each point (pixel) of the image. Slope is an image generated from Digital Elevation Model (DTM) and gives the value in degrees or percent of the magnitude of slope at each pixel of image.

Topographic studies have enabled us to identify low lying areas where rainwater can stagnate and cause flooding. However, stagnation of water does not depend only on topography but also on soil nature. Hence interest of doing geotechnical tests.

Topographic studies must be supplemented by geotechnical studies to identify soil nature and certain dimensioning parameters (Figure 5).

\subsection{Geotechnical Studies}

A manual survey was carried out at study site at three different locations. This $1.80 \mathrm{~m}$ deep hole gave a good idea of different types of soil present in Sampathé. These three samples $(1,2,3)$ are subject of a geotechnical study carried out in Geotechnical Laboraty of Thies University in order to know physical soil characteristics soil.

The tests carried out on these samples are particle size analysis, sand equivalent test and soil permeability test. The results obtained will be used for design and sizing of network.
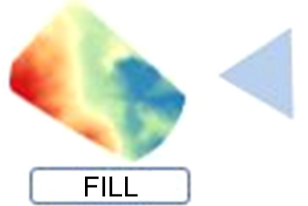

FILL

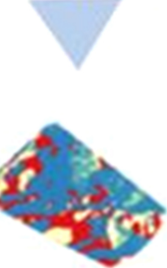

FLOW DIRECTION
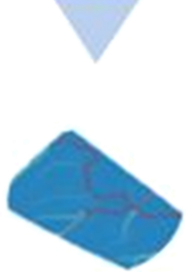

FLOW ACCUMULATION
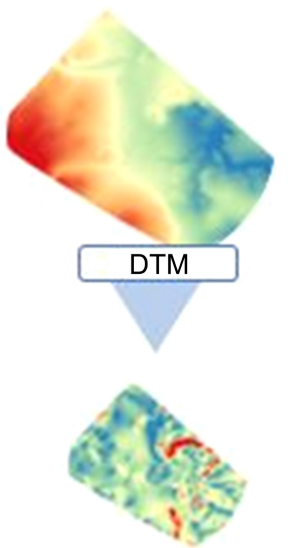

$$
\text { SLOPE }
$$

Figure 5. Steps in calculating topographic index. 


\subsection{Network Design and Sizing}

Climatic regime of our study area is determined like all of West Africa by rainfall regime. These depend on contribution of monsoon and its distribution over the years is marked by great variability (Bonaventure et al., 2013) [22]. Rainfall regime depends on the type of precipitation (dew, downpour, wet precipitation), on seasonal rhythm, on temporal variability (succession of rainy periods). Annual modulus $(\mathrm{P})$ which is expressed in $\mathrm{mm} /$ year is sum of all precipitations that have fallen during whole year. This average is calculated over a period of 30 years (Figure 6).

Design and sizing of sewerage network depend on characterization of the watersheds that are located on outskirts and inside Sampathé district. A watershed represents geographic unit on which analysis of hydrological cycle and its effects is based; it is a hydrological closed elementary surface whose excess precipitation evaporates or runs out at outlet [23] (Figure 7 and Figure 8). Watershed has several characteristics, which are surface, average slope, length, and shape. Parameters such as delineation of watersheds, length, average slope, runoff coefficient and time of concentration enter directly into determination of runoff rate. Watersheds obtained from the SRTM data have a metric precision; they allow having an idea on the quantity of runoff water, to choose an estimation method to know the position of the hydraulic structures in periphery of zone under study.

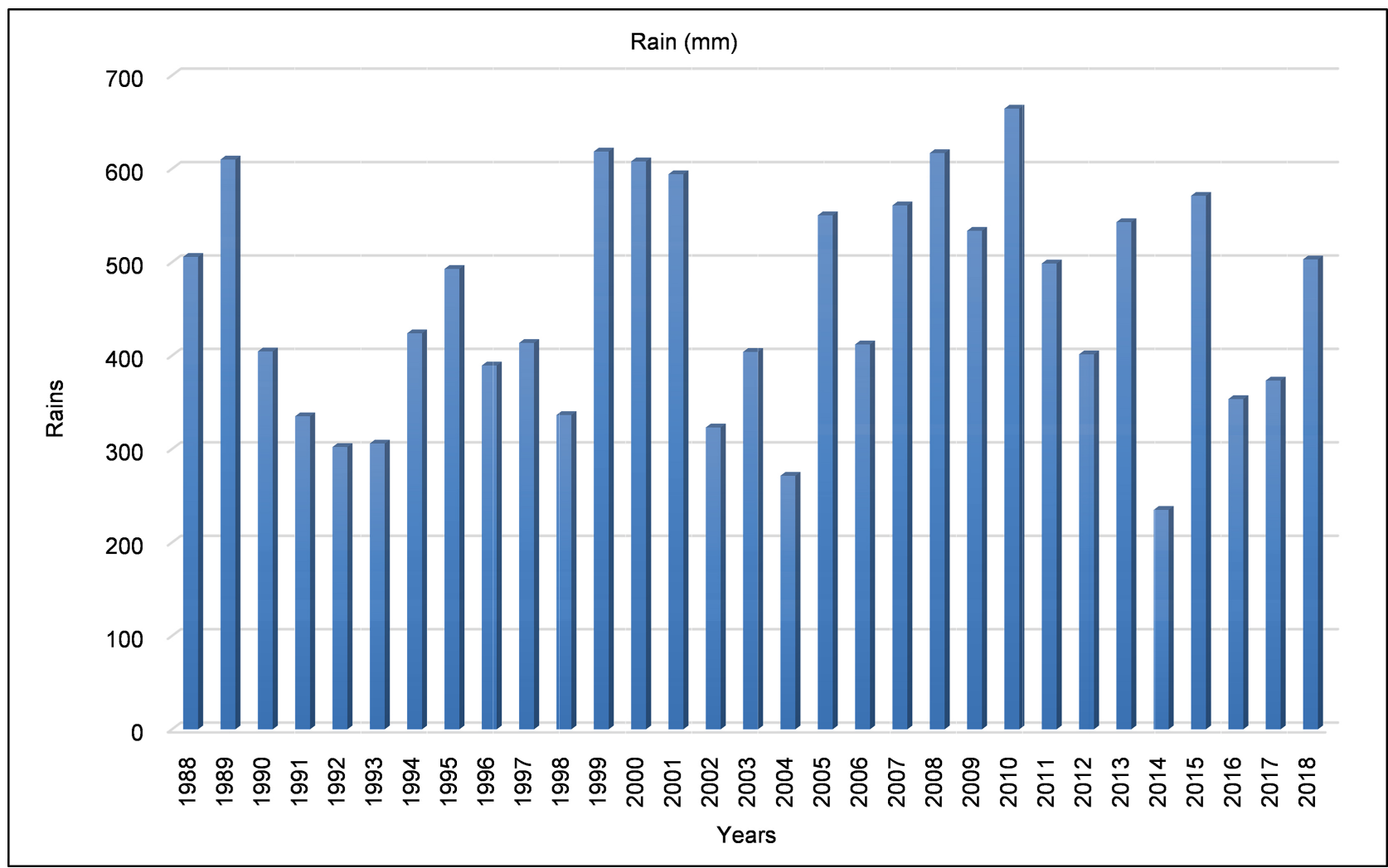

Figure 6. Variation in rainfall from 1988 to 2018 (Thiès station). 


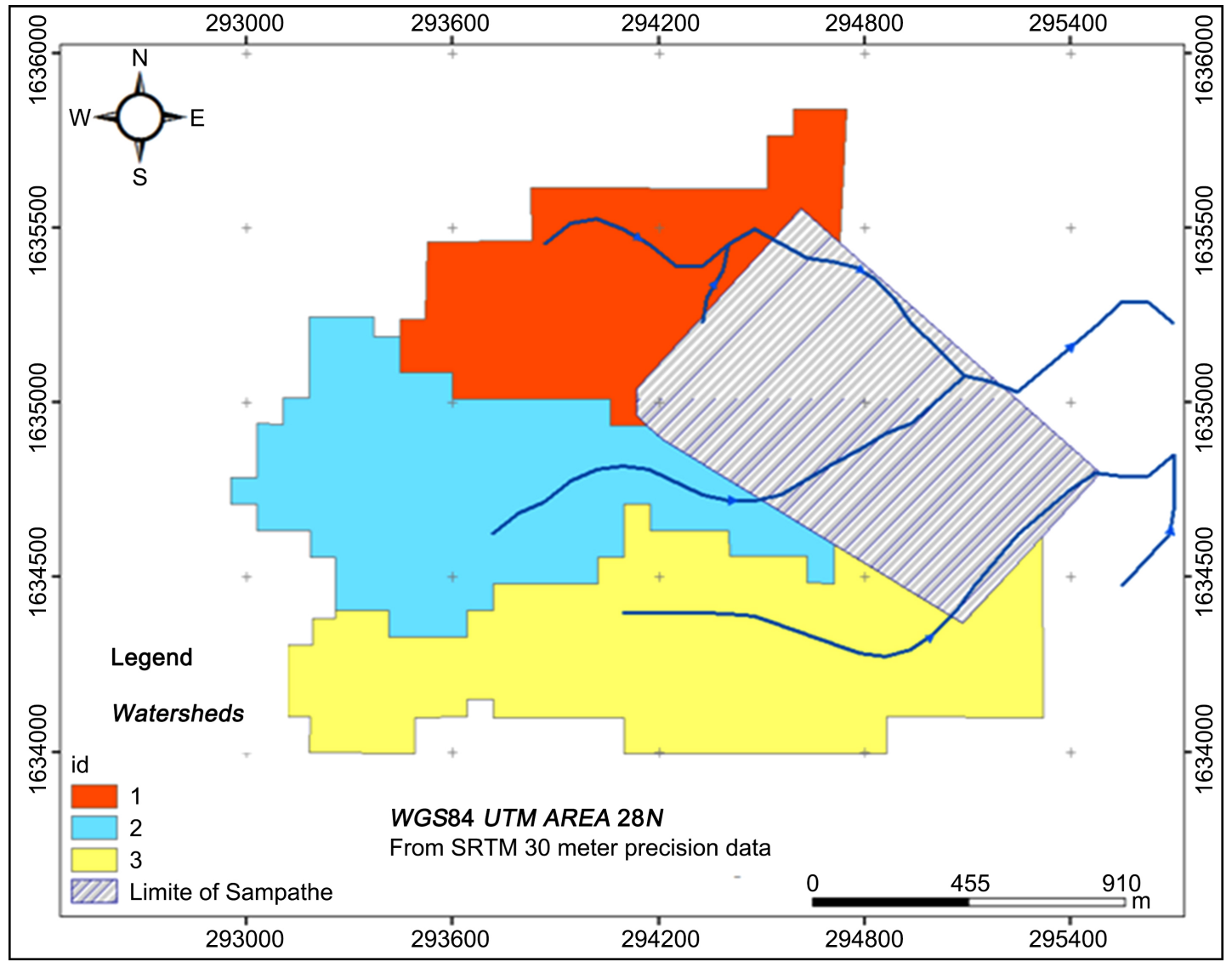

Figure 7. Watersheds on the outskirts of Sampathé.

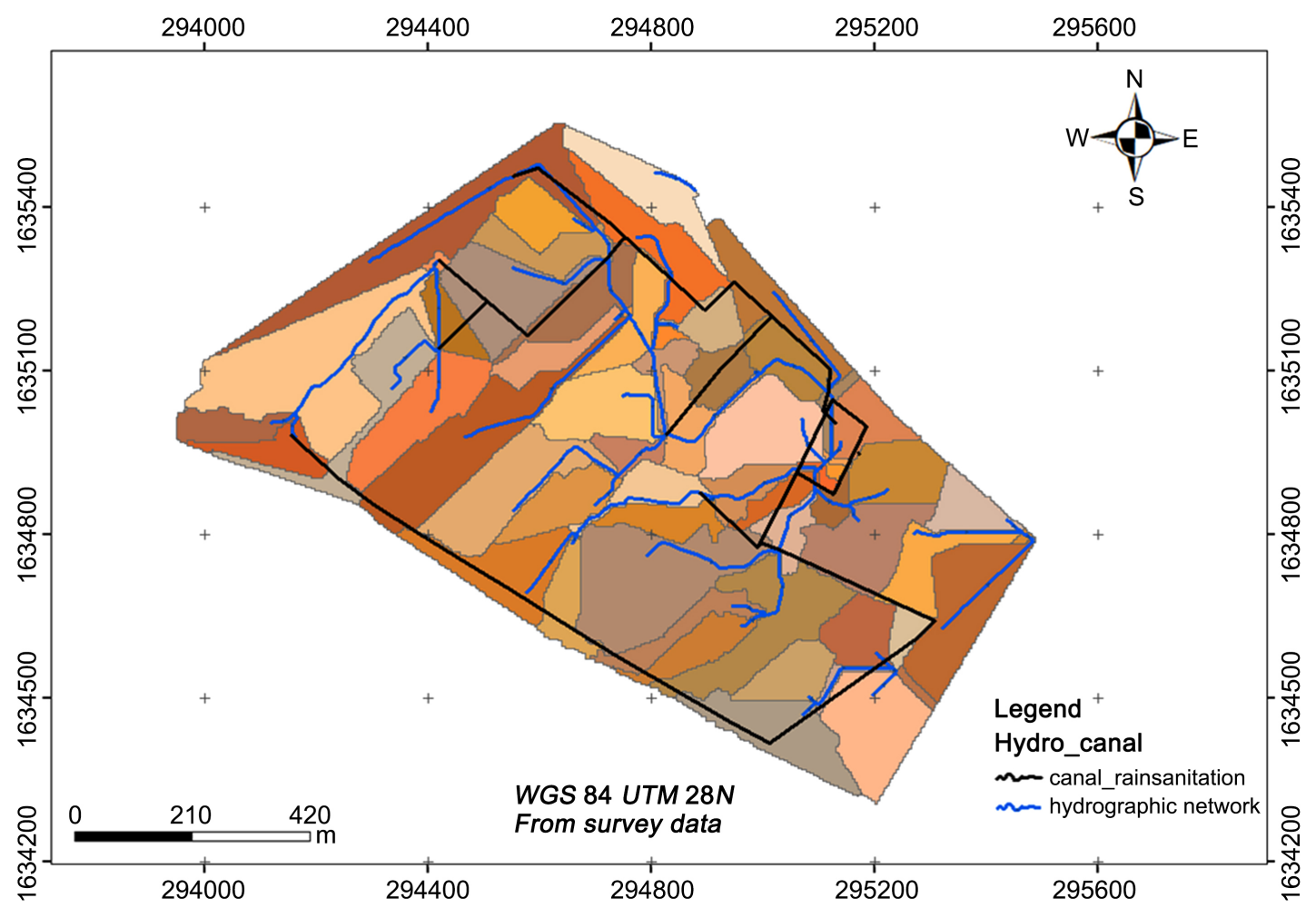

Figure 8. Map of the sub-watersheds. 
To carry out a storm water design and sizing study, it is advisable to work with topographic data with good precision. They make it possible to have characteristics of watersheds, which are inside the zone and to be able to determine position of hydraulic structures as well as drainage network in order to ensure a gravity flow.

The dimensioning method adopted is that of Caquot that makes it possible to calculate the water flow. It represents an evolution of rational method by avoiding being limited by estimation of concentration time, on one hand, and by taking into account possibilities of water storage in watershed, on other hand.

The point flow is calculated for a return period $\mathrm{T}=10$ years (Equation (1)) Caquot's formula

$$
Q p=\left(\frac{a \mu^{b}}{6(\beta)+\delta}\right)^{\frac{1}{1-b f}} C^{\frac{1}{1-b f}} I^{\frac{c b}{1-b f}} A^{\frac{1-s+d f}{1-b f}}
$$

With:

$Q p$ in $\mathrm{m}^{3} / \mathrm{s}$.

$A$ in ha.

Iin m.p.m.

Nine parameters: $a, b, \varepsilon$ rain parameters.

$\beta+\delta$ Characterizing the mode of transformation of rain into debit.

$\mu, c, d, f$ characterizing the watershed.

$C$ : Coefficient of runoff.

The results of the regression calculations for Montana coefficients ( $a$ and $b$ ) are reported in Table 1.

The shape of watershed can be collected or elongated and has a very great influence on flow calculation hence the need to correct the flow $\mathrm{Q}$. The corrected characteristics of watersheds are summarized in Table 2.

Table 1. Montana's coefficients as a function of the return period $\mathrm{T}=10$ years.

\begin{tabular}{cc}
\hline & $\mathrm{T}=10$ ans \\
\hline $\mathrm{a}$ & $\mathrm{b}$ \\
\hline 5.891 & 0.782 \\
\hline
\end{tabular}

Table 2. Watershed assembly formulas.

\begin{tabular}{|c|c|c|c|c|c|}
\hline Watersheds & Equivalent surface & Equivalent length & Equivalent slope & Equivalent elongation & Runoff coefficient \\
\hline Serial watersheds & $\sum A_{t}$ & $\sum L_{i}$ & {$\left[\frac{\sum L_{i}}{\sum \frac{L_{i}}{\sqrt{I_{i}}}}\right\rfloor$} & $\frac{\sum L_{i}}{\sum \sqrt{A_{i}}}$ & $\frac{\sum C_{i} * A_{i}}{\sum A_{i}}$ \\
\hline Parallel watersheds & $\sum A_{t}$ & $\operatorname{Max}\left(L_{i}\right)$ & $\frac{\sum I_{i} * Q_{i}}{\sum Q_{i}}$ & $\frac{L_{i} * Q_{\max }}{\sqrt{\sum A_{i}}}$ & $\frac{\sum C_{i} * A_{i}}{\sum A_{i}}$ \\
\hline
\end{tabular}

$A_{i}=$ Surface of elementary watershed (i); $L_{i}=$ flow length of elementary watershed (i); $C_{i}=$ Coefficient of runoff of the elementary basin (i); $Q_{i}=$ Flow to evacuate from watershed (i). 
Corrective values are obtained through relation using equivalent elongation (M) (Table 2, Equation (2))

$$
m=\left(\frac{M}{2}\right)^{x} \quad x=\frac{0.84 *(-b)}{1+0.29 *(-b)}
$$

The corrected value of the flow is obtained by the following relation (Equation (3))

$$
Q_{c}=m * Q
$$

The diameter of pipes will be deduced from corrected flow using Strickler Manning formula (Equation (4)).

$$
D=\left[\frac{4^{\frac{2}{3}} \times Q}{K_{s} \times I^{\frac{1}{2}}}\right]^{\frac{3}{2}}\left\{\begin{array}{l}
Q: \text { the corrected flow } \\
K_{s}: \text { Manning strickler coefficient } \\
I: \text { Slope } \\
D: \text { The diameter of the section }
\end{array}\right.
$$

\subsection{Development of a Database with Geographical Reference}

Data represent most important components of GIS. All data acquired (topographic, dimensioning) are integrated into a database with spatial reference to constitute core of our GIS (Table 3).

\section{Results}

Results obtained in this study are compiled in Table 1 to Table 6 and in Figure 9 to Figure 14.

\subsection{Topographic Results}

Figure 9 describes initial situation of study area. It shows all elements existing on ground, mainly island heads, the roadsides, various existing and visible networks (electrical networks, telephone network), railway network as well as other characteristic elements.

Data obtained with Cholesky leveling made it possible to produce the digital model of the field using its interpolation by delauney triangulation (Figure 10). It shows the lowest points at the level of Sampathé district located at level of upstream of Dalot, on railway line (1) and towards the wastewater pumping station (2).

Table 3. BDRS data.

\begin{tabular}{ccc}
\hline Point Data & Linear Data & Surface Data \\
\hline Manholes & Collectors & Parcel \\
Gutter & Roads & Neighborhood \\
& & Watersheds \\
& & Retention basin
\end{tabular}




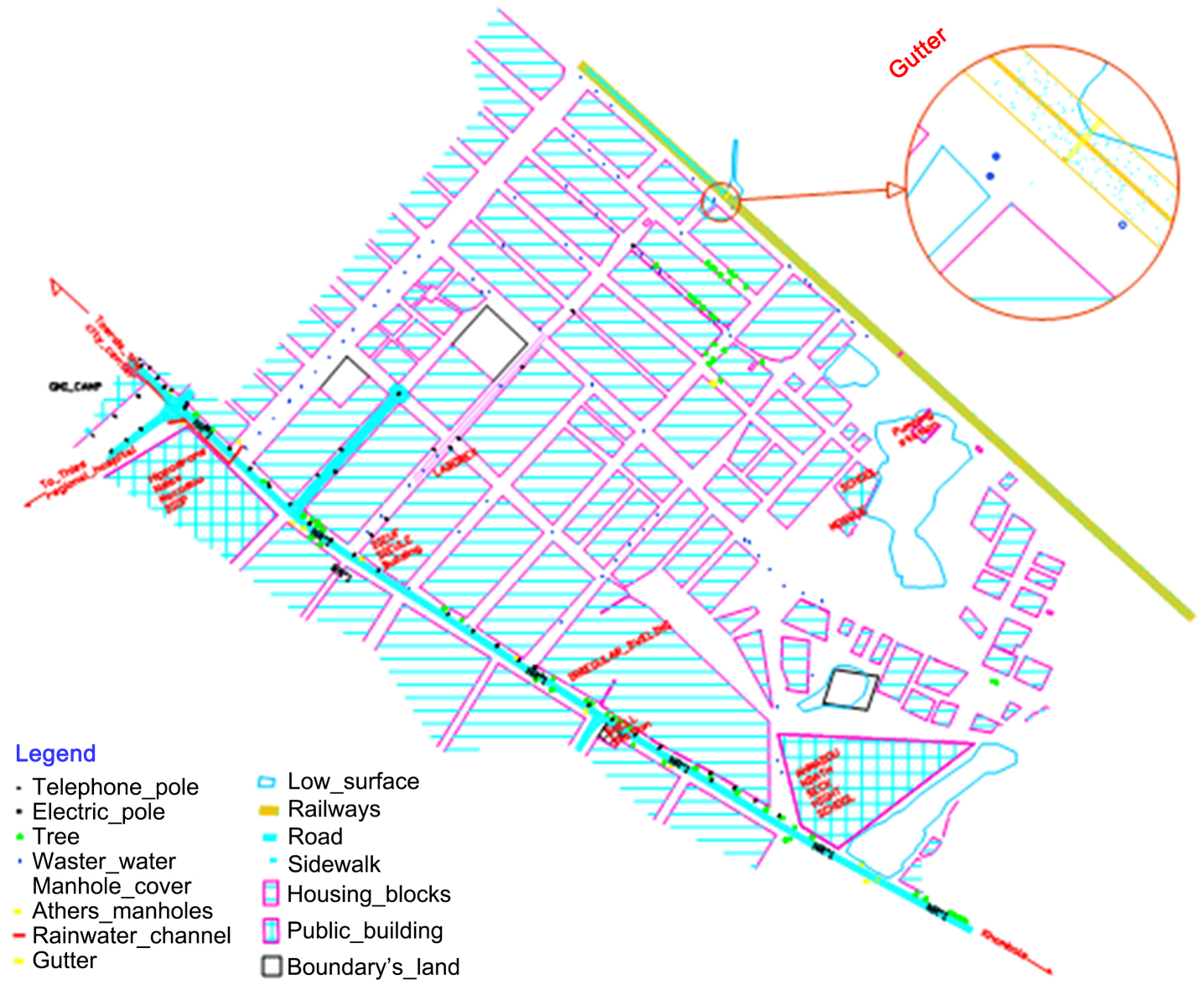

Figure 9. Sampathé inventory plan.
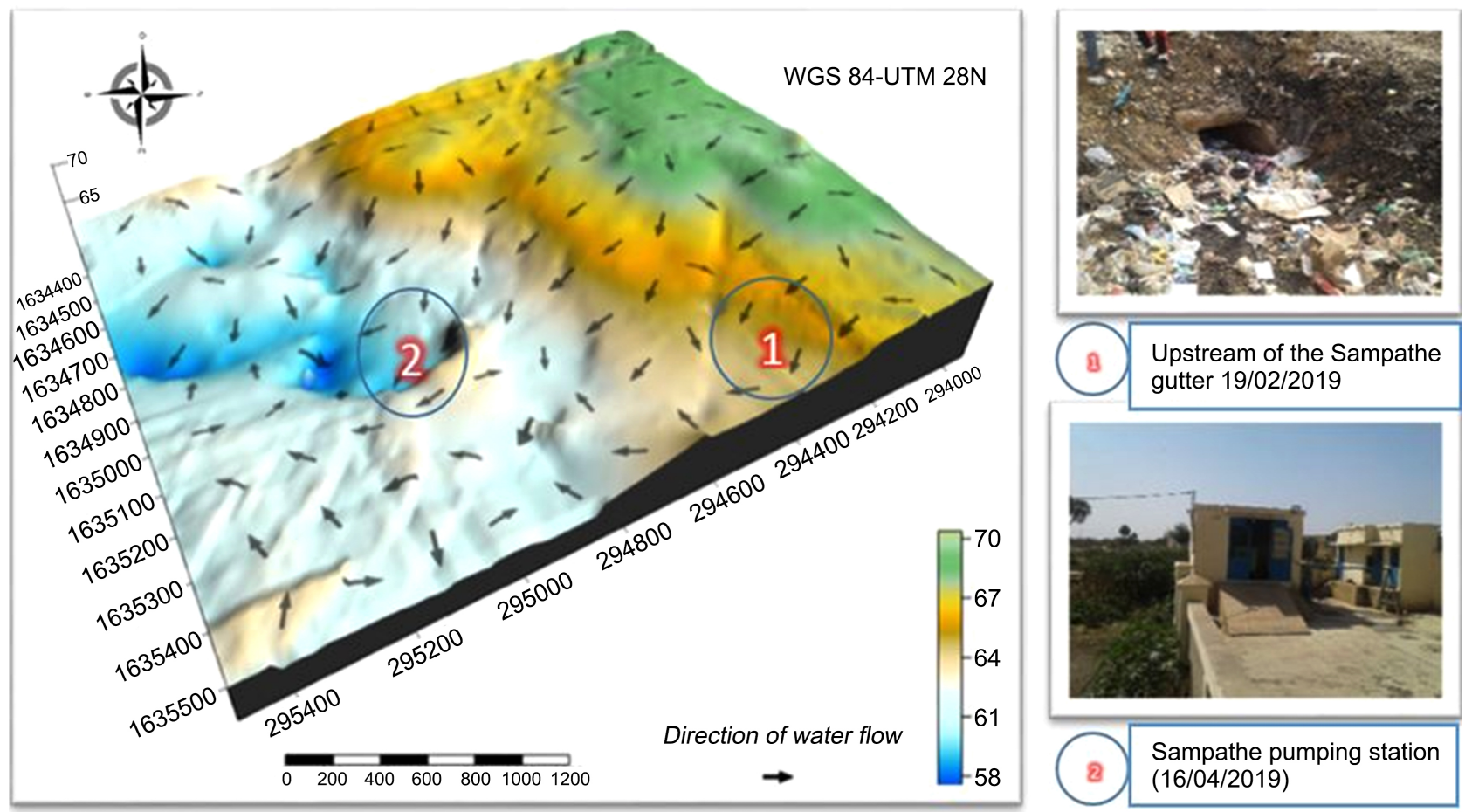

Figure 10. DTM-TN of study area with the Surfer 13 software. 
Figure 10 describes the outlet, the point where runoff water converges in Sampathé district, (outline drawn in blue) located towards the wastewater pumping station. This demonstrates compliance with the results obtained from the DEM.

The results of topographic index calculation show variations in increasing values ranging from non-flooding locations to potentially flooding areas. For this case, the topographic index varies from -8.70415 to 12.4898 (Figure 9). Very high values are noted towards wastewater pumping station; as well as in the north towards scupper, which constituted natural outlet of Sampathé. Average, or even fairly large, TI values are also noted "randomly" in certain places in study area: this suggests presence of numerous water receptacle areas. However, distribution of the TI suggests that runoff is heading to outlet near wastewater pumping station (Figure 11). This is what confirms the position of outlet.

However, IT is necessary but not sufficient in distinguishing flood zones. Indeed, results of index calculation were based solely on topography of the site. It therefore does not take into account either geotechnical characteristics or land use.

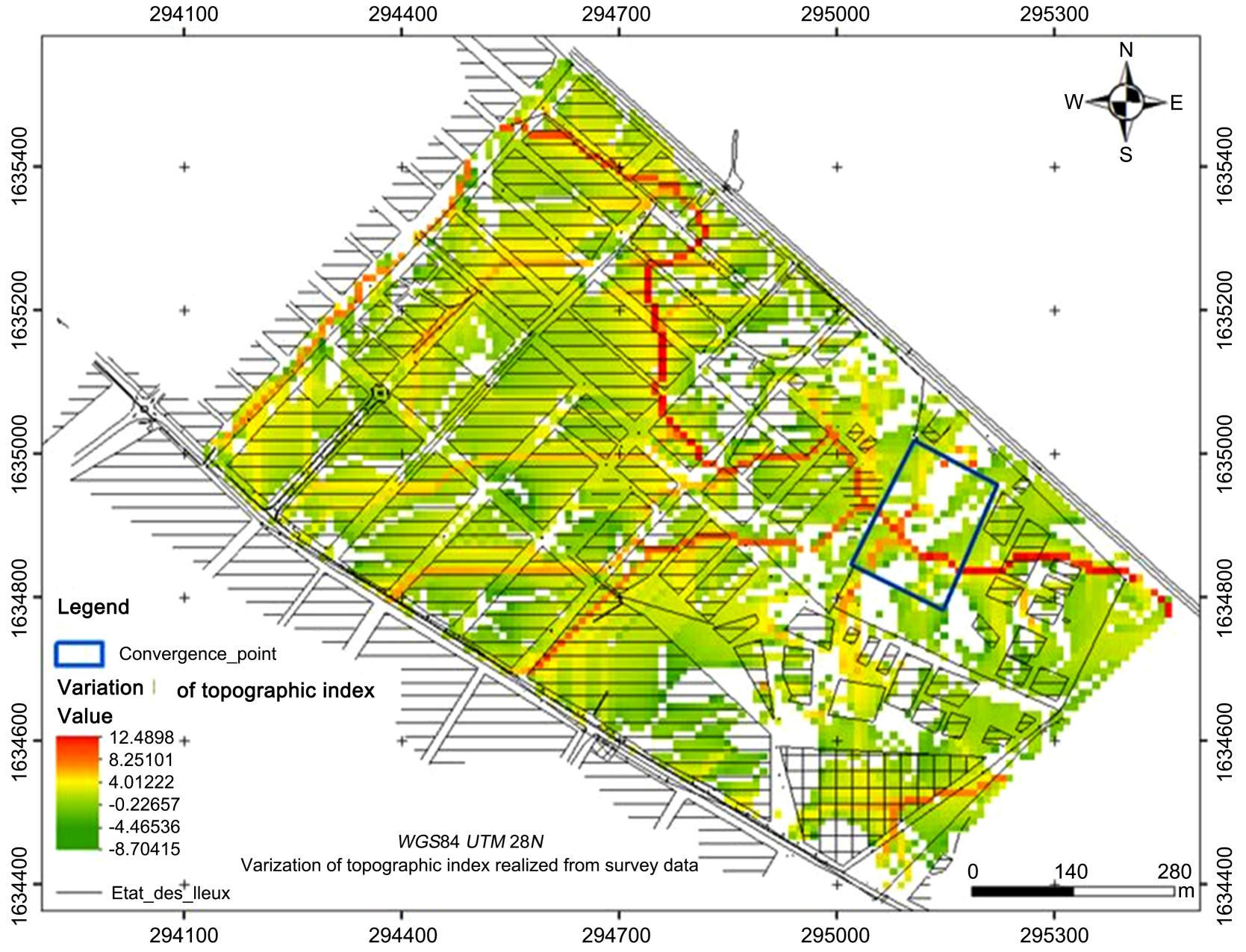

Figure 11. Map of the topographic index of Sampathé district. 
For a more rigorous study in the determination of wetlands, it is mandatory not only to have geotechnical data of the site, but also to know context (that is to say the type of development) of the zone of application of the project.

\subsection{Geotechnical Results}

Results obtained through geotechnical tests are distributed as follows: granulometric results allow us to determine scale and classification of grains contained in our sampling (Figure 12(a); Figure 2(b) and Figure 12(c), Table 4).

$$
\mathrm{Cu}=\frac{\mathrm{D} 60}{\mathrm{D} 10} ; \mathrm{C}_{\mathrm{c}}=\frac{\mathrm{D} 30^{2}}{\mathrm{D} 60 \times \mathrm{D} 10}
$$

$\mathrm{Cu}$ : Coefficient of uniformity;

$\mathrm{C}_{\mathrm{c}}$ : Curvature coefficient;

D10: Diameter corresponding to $10 \%$ passing $(\mathrm{mm})$;

D30: Diameter corresponding to $30 \%$ of loop $(\mathrm{mm})$;

D60: Diameter corresponding to $10 \%$ passing $(\mathrm{mm})$;

$\mathrm{Mf}=$ finess module.

Granulometric results show the sand studied is not rich in fine elements, it has a discontinuous granulometry. That is, all the grain families are present and proportionately distributed, hence our studied sampling is poorly graded clean sand (Table 4). The sand equivalent test is an indicator that characterizes the cleanliness of a sand or gravel. It indicates the content of fine elements, mainly of clay, vegetable or organic origin at the surface of the grains. The sand equivalent test is an indicator to characterize the cleanliness of a sand or gravel. It indicates the content of fine elements, mainly of clay, vegetable or organic origin at the surface of the grains.

Table 6 describes classification of soil and allows to classify the sand studied according to values of the Sand Equivalent view (ESv) and the Equivalent of piston sand (Esp) (Table 5).

Results of sand equivalent test show that $\mathrm{v} \leq 65 \%$, ESp $\leq 60 \%$ so we can deduce that we have a clayey sand from which risk of shrinkage or swelling. Results of permeability test allow type of sand formation (permeable, semi-permeable or impermeable sand) to be classified according to the grading of grains. According to (Breul, 2015) [25] in Table of material classification according to coefficient of permeability, our studied sand has a bad permeability that is to say that we are dealing with a semi-permeable soil.

\subsection{Results of Network Design}

Figure 13 describes framework of sewerage network consisting of two primary pipes, four secondary pipes, a tertiary pipe, ninety-two manholes and retention basin.

Rainwater drainage network thus allows population of Sampathé district, during rainy season, to continue to carry out their socio-economic activities in order to ensure a better living environment. 


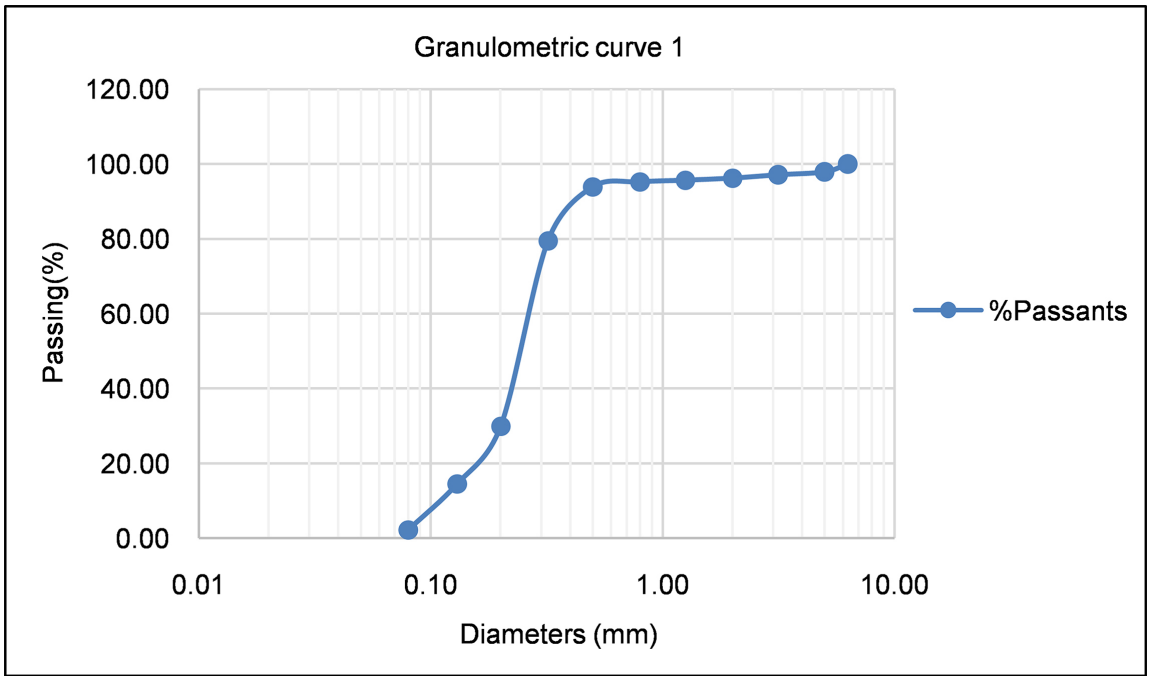

(a)

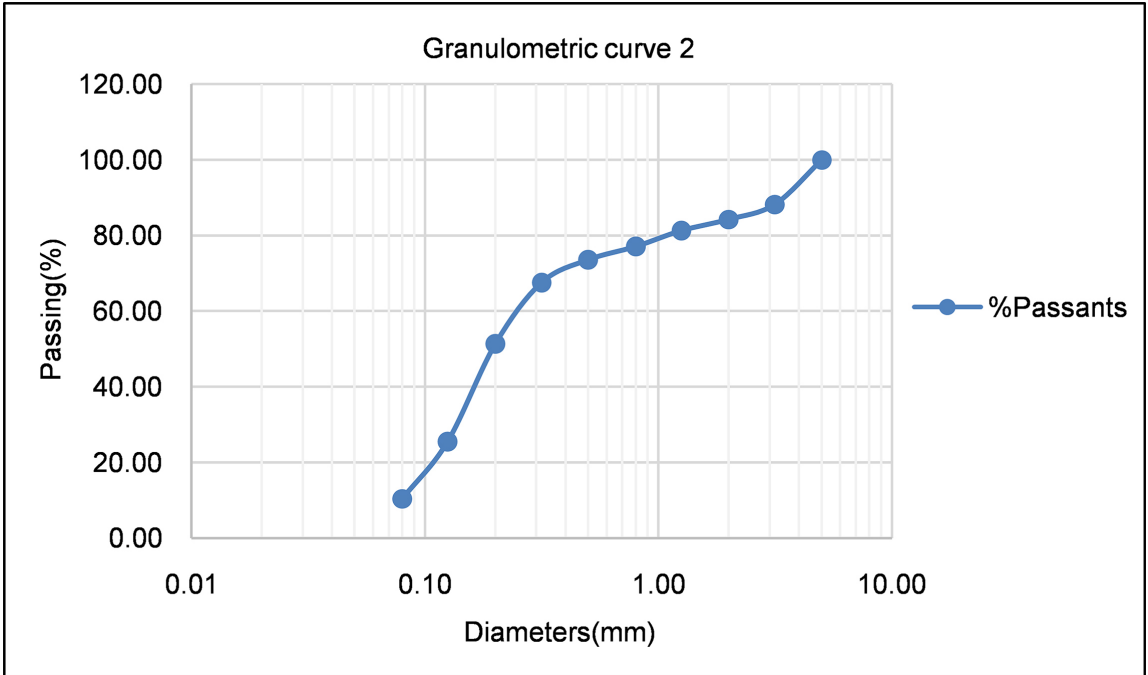

(b)

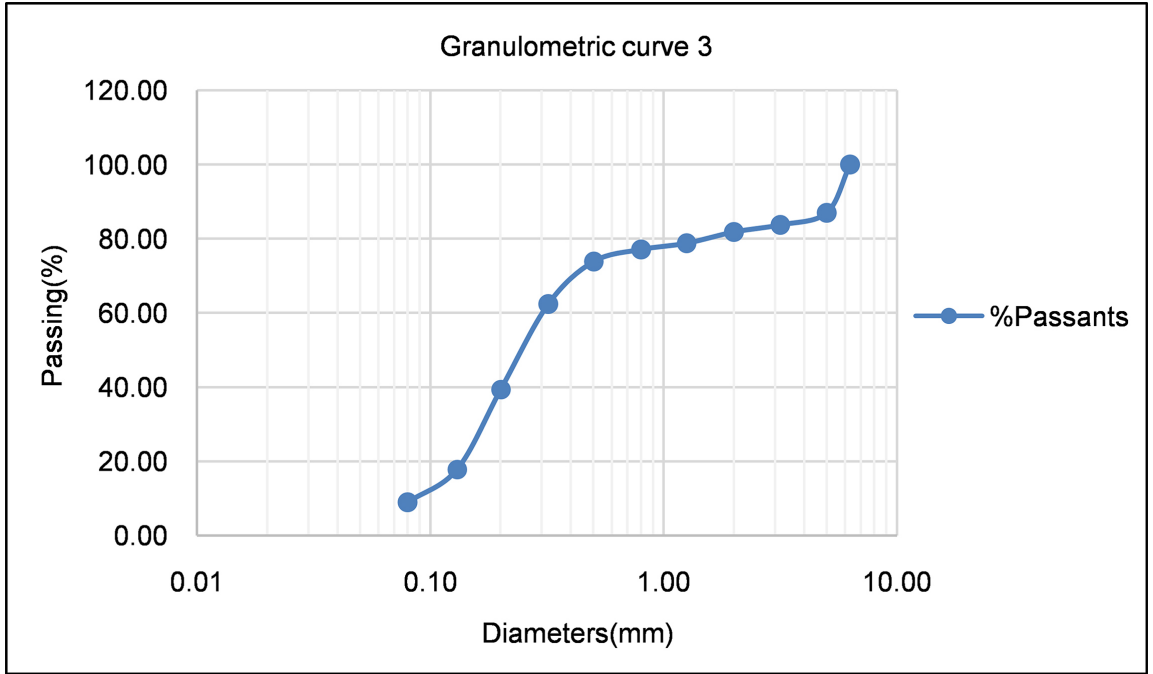

(c)

Figure 12. (a) Particle size curves; (b) Particle size curves; (c) Particle size curves. 
Table 4. Summary of results of particle size analysis.

\begin{tabular}{cccc}
\hline Coefficients & Sample 1 & Sample 2 & Sample 3 \\
\hline $\mathrm{Cu}$ & 1.137 & 1.325 & 1.5 \\
$\mathrm{Cc}$ & 1.022 & 1.3 & 1.215 \\
$\mathrm{Mf}$ & 2.973 & 4.36 & 3.89 \\
Results & $\begin{array}{c}\text { Poorly graded } \\
\text { clean sand }\end{array}$ & $\begin{array}{c}\text { Poorly graded } \\
\text { clean sand }\end{array}$ & $\begin{array}{c}\text { Poorly graded } \\
\text { clean sand }\end{array}$ \\
\hline
\end{tabular}

Table 5. Sand equivalent test results.

\begin{tabular}{cccc}
\hline & Sand equivalent test $\mathrm{M}=120 \mathrm{~g}$ & \\
\hline Sampling & Sample 1 & Sample 2 & Sample 3 \\
\hline $\mathrm{h}_{1}$ (sediment + flocculate) & 118.00 & 227.00 & 180.00 \\
$\mathrm{~h}_{2}$ (sediment) & 98.00 & 98.00 & 97.00 \\
$\mathrm{~h}_{2}^{\prime} \quad$ (Piston end) & 72.00 & 42.00 & 39.00 \\
Sight ES (\%) & 83.05 & 43.17 & 53.89 \\
Piston ES (\%) & 61.02 & 18.50 & 39.00 \\
Medium Sight ES (\%) & & 60.04 & \\
Medium piston ES (\%) & & 51.00 & \\
\hline
\end{tabular}

Table 6. Classification of sand according to their sand equivalent.

\begin{tabular}{ccc}
\hline ESv & ESp & Nature and quality of land use \\
$\mathrm{ESv} \leq 65$ & $\mathrm{ESp} \leq 60$ & $\begin{array}{c}\text { Clayey sand, there is a risk of shrinkage } \\
\text { and swelling }\end{array}$ \\
$65 \leq \mathrm{ESv} \leq 75$ & $60 \leq \mathrm{ESp} \leq 70$ & $\begin{array}{c}\text { Slightly clayey sand of acceptable cleanliness } \\
\text { for hydraulic concrete }\end{array}$ \\
$75 \leq \mathrm{ESv} \leq 85$ & $70 \leq \mathrm{ESp} \leq 80$ & $\begin{array}{c}\text { Clean sand with a low percentage of fine } \\
\text { clayey suitable for quality concrete } \\
\mathrm{ESv} \geq 85\end{array}$ \\
$\mathrm{ESp} \geq 85$ & $\begin{array}{c}\text { Very clean sand: the absence of fine clay; } \\
\text { risk of causing a plasticity defect }\end{array}$ \\
\hline
\end{tabular}

\subsection{GIS Results}

They make it possible to make requests and spatial analyzes for location of various components of sewerage network, in particular storm water network, manholes and retention basin. Figure 14 describes requests on pipelines and shows all information of different components in database allowing for straightforward rapid intervention in event of a problem. 


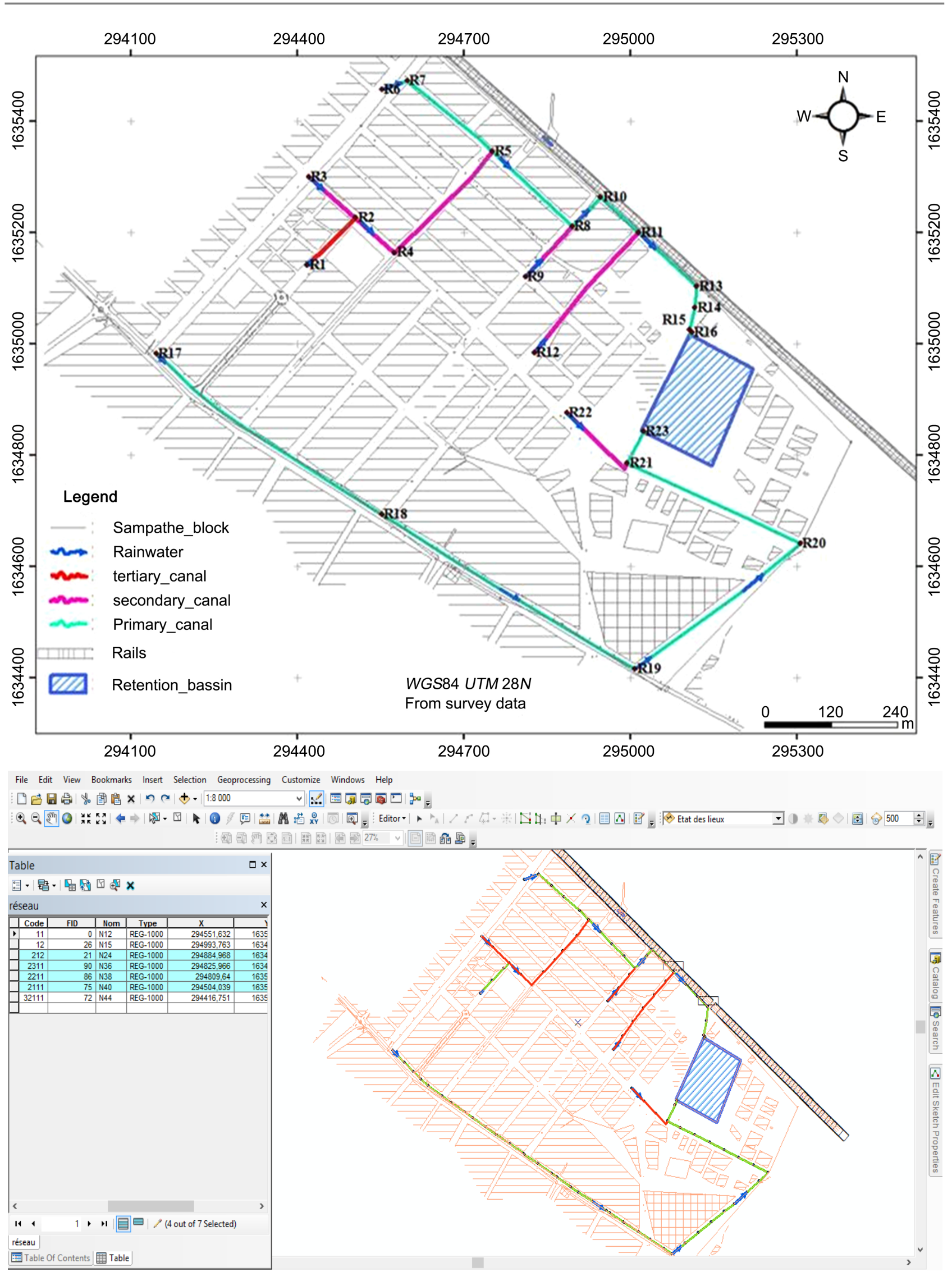

Figure 13. Network framework. 


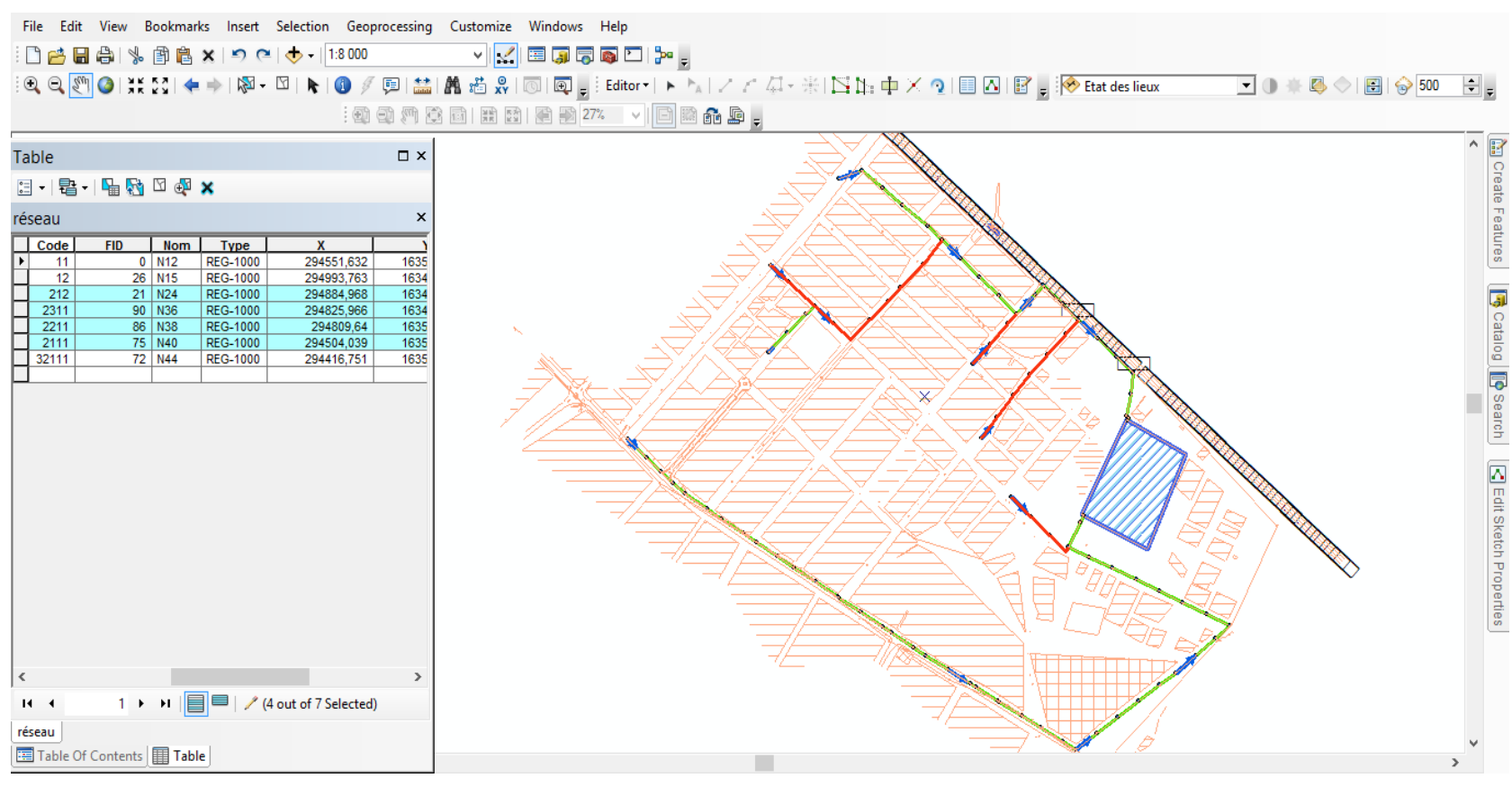

Figure 14. Queries on first primary and secondary channel.

\subsection{Discussions}

Results compilation shows that Sampathé district is a bottom compared to peripheral districts. Hence interest of designing storm water sanitation network in district by proposing a Geographic Information System to ensure the management of database. Diop Aminata et al. 2014 [26] have shown that analysis of flood vulnerability system is an essential part in reducing risk of flooding. This analysis is in perfect correlation with our study for a sewerage system separated from wastewater. This justified topographical and geotechnical studies associated with a GIS for a lasting solution to the floods in Sampathé.

In this study, topographic acquisition data is done to a more precise centimeter precision than often-used SRTM (metric precision) data. This observation is confirmed by Djaouga et al. (2017) [27] which shows DEMs used in carrying out their mapping study (2017) of flood-prone areas in municipalities of Abomey-Calavi, Seme-Podji and So-ava in Benin have a resolution of $30 \mathrm{~m}$. This shows the limits of their work and confirms reliability of our results obtained with the sizing of the stormwater treatment network.

In report on preparation for e management of natural perils and risks linked to climate change in Dakar, which is a spatial and institutional approach (June 2009). Hyoung Gun Wan et al., (2009) [28] uses in their action plan a spatial database for local disaster management in Dakar metropolitan region to ensure wide access and practical training of local agency staff. These comments confirm the importance of having a spatial database to ensure the proper management of a phenomenon.

All of these results enabled the sizing of a sewerage network coupled with a Geographic Information System, which could serve as a prototype in Senegal, for 
good management of sanitation networks. This is the example of the city of Gafsa in Tunisia where a GIS application for wastewater and rainwater treatment is developed to ensure network management by DHIEB (2010) [29]. An ONAS GAFSA application is used to facilitate establishment of a database. The latter allows several users to access same information facilitating management, control and monitoring of operation of sanitation network, wastewater and rainwater.

This Geographic Information System allows all operators in terms of development to find their way around and have a more global view. In fact, latter makes it possible to ensure accessibility of underground network; to update network plans, thus also allowing identification and rapid intervention on network.

\section{Conclusions}

This study allowed designing a storm water sanitation network integrated into a Geographic Information System. For this purpose, a reconnaissance study was carried out to find that Sampathé is a bottom compared to surrounding districts (Diamaguene, Hersent). In addition, scupper is the natural outlet and no longer allows correct drainage of rainwater. Topographical studies carried out were of crutial importance because they enabled us to better understand geomorphology of the land. Determination of geotechnical characteristics of soil permitted to know the nature of soil and certain design parameters such as runoff coefficient for the design. Topographic data combined with rainfall data for Thiès area enabled not only to design the framework of network but also to size storm water drainage network in Sampathé district.

All information S obtained are integrated into a Geographic Information System to ensure management of the network and provide population with a better living environment. In addition, the route did not encroach on current homes or future homes that appear in development plan. Environmental and social impact studies do not show any major negative effects that could prevent the project from being carried out.

According to reference system on underground rainwater management structures, lifespan of sanitation structures is linked to regular maintenance allowing the proper flow of water. It may also be altered in event of accidental pollution. There is not enough lifespan feedback to date. The latter is generally compromised, whatever type of structure, by presence of networks: in dense urban areas, multiplicity of concessionaires in spaces increases the number of small interventions. French regulations impose depreciation of sanitation networks and propose regulatory depreciation rates of 50 to 60 years for sanitation networks.

However, current pipe renewal rate would lead to longer operating lives of up to 80 or even 100 years. Application of this study would be a lasting solution to floods in Sampathé district.

To enhance the lifespan and better monitor the network, it would be impor- 
tant to set up an application for services in charge of sanitation like Nation Office of Sanitation of Senegal and municipal technical services in Senegal (ONAS, municipal technical services).

\section{Acknowledgements}

We thank all technicians, engineers and professors who contributed to this work on floods.

\section{Conflicts of Interest}

The authors declare no conflicts of interest regarding the publication of this paper.

\section{References}

[1] Banque, M. (2015) Rapport sur le développement dans le monde. Revue de P urbanisation villes émergentes pour un Sénégal émergent, $126 \mathrm{p}$.

[2] Chenal J. (2013) La ville ouest-africaine. Modèles de planification de l'espace urbain. VuesDensemble, Métis Presses, Genève.

[3] Fujiki, K. (2017) Etude prospective des impacts sociaux d'une inondation majeure en région Ile-deFrance. Disparités socio-spatiales dans la prise en charge des populations franciliennes en situation de crise et de post-crise: Une analyse cartographiée et quantifiée des besoins des ménages, de l'évacuation à la reconstruction (PhD Thesis). Université Jean Moulin Lyon 3, Lyon

[4] Lindell, M. (2013) Recovery and Reconstruction after Disaster. In: Bobrowsky, P.T., Ed., Encyclopedia of Natural Hazards, Springer, Dordrecht, 812-824. https://doi.org/10.1007/978-1-4020-4399-4_285

[5] Ahern, M., Kovats, R.S., Wilkinson, P., Few, R. and Matthies, F. (2005) Global Health Impacts of Floods: Epidemiologic Evidence. Epidemiologic Reviews, 27, 36-46. https://doi.org/10.1093/epirev/mxi004

[6] Brémond, P., Grelot, F. and Agenais, A.-L. (2013) Review Article: Economic Evaluation of Flood Damage to Agriculture-Review and Analysis of Existing Methods. Natural Hazards and Earth System Science, 13, 2493-2512. https://doi.org/10.5194/nhess-13-2493-2013

[7] Torterotot, J.-P. (1993) Le coût des dommages dus aux inondations: Estimation et analyse des incertitudes. Thèse doctorat Sciences et Techniques de l'Environnement, École des Ponts ParisTech, Paris, 261 p.

[8] Aldrich, D. (2012) Building Resilience: Social Capital in Post-Disaster Recovery. The University of Chicago Press, Chicago. https://doi.org/10.7208/chicago/9780226012896.001.0001

[9] Baade, R., Baumann, R. and Matheson, V. (2007) Estimating the Economic Impact of Natural and Social Disasters, with an Application to Hurricane Katrina. Urban Studies, 44, 2061-2076. https://doi.org/10.1080/00420980701518917

[10] Bolin, R. and Stanford, L. (1991) Shelter, Housing and Recovery: A Comparison of US Disasters. Disasters, 15, 24-34. https://doi.org/10.1111/j.1467-7717.1991.tb00424.x

[11] Leon, G. (2004) Overview of the Psychosocial Impact of Disasters. Prehospital and Disaster Medicine, 19, 4-9. https://doi.org/10.1017/S1049023X00001424 
[12] Thieken, A.H., Bessel, T., Kienzler, S., Kreibich, H., Müller, M., Pisi, S. and Schröter, K. (2016) The Flood of June 2013 in Germany: How Much Do We Know about Its Impacts. Natural Hazards and Earth System Sciences, 16, 1519-1540. https://doi.org/10.5194/nhess-16-1519-2016

[13] Vigdor, J. (2008) The Economic Aftermath of Hurricane Katrina. Journal of Economic, 22, 135-154. https://doi.org/10.1257/jep.22.4.135

[14] Bates, B., Kundzewicz, Z.W., Wu, S.H. and Palutikof, J. (2008) Le changement climatique et l'eau, document technique publié par le Groupe d'experts intergouvernemental sur l'évolution du climat. Secrétariat du GIEC, Genève, $236 \mathrm{p}$.

[15] Direction de la Protection Civile (2008) Projet d'appui au programme national de prevention, de reduction et de gestion des catastrophes naturelles (DPC-PNUD). Analyse institutionnelle des plates-formes nationales et des organes referents de la Réduction des Risques de Catastrophes. Première partie: Etude de cas du Sénégal.

[16] République du Senegal (2010) Rapport d'Evaluation des besoins POST Catastrophe Inondations urbaines à Dakar 2009.

[17] Mame Demba Thiam (2011) Le syndrome des inondations au Sénégal. Presses Universitaires du Sahel, Dakar, Vol. 1, 225 p.

[18] Thiam, A., Faye, P.S., Sarr, S.M. and Diallo, D.S.Y. (2020) Flood Management in Saint-Louis City of Senegal by Stabilizing the Breach. American Journal of Environmental Protection, 8, 70-77.

[19] ANSD (2019) Thiès Situation Economique et Sociale régionale. 218 p.

[20] Le Moigne, P., Boone, A., Belamari, S., Brun, E., Calvet, J.-C., et al. (2012) SURFEX Scientific Documentation. Technical Report, Centre National de Recherches Météorologiques, Toulouse.

[21] Milles, S. and Lagofun, J. (1999) Topographie Et Topometrie Moderne, Tome 1. Techniques de Mesure (Fr) (Eyrolles, 1999) (534s)

[22] Roger, D. and Lauzon, E.P. (1996) Topométrie générale. Troisième édition, Presses internationales Polytechnique, Montreal, $647 \mathrm{p}$.

[23] Roger, D. and Lauzon, E.P. (1996) Presses inter Polytechnique. Surveying, 652 p.

[24] Kerlocl'h, B. and Maelstaf, D. (2014) Le dimensionnement des réseaux d'assainissement des agglomérations. 52 .

[25] Breul, P., Haddani, Y. and Gourvès, R. (2008) On Site Characterization and Air Content Evaluation of Coastal Soils by Image Analysis to Estimate Liquefaction Risks. Canadian Geotechnical Journal, 45, 1723-1732. https://doi.org/10.1139/T08-090

[26] Diop, A., Niang, C.I., Mbow, C. and Daouda, A.D. (2014) Etude de la vulnérabilité de Thiaroye sur Mer aux inondations: Facteurs et effets. Nouvelle Série, No. 18, 186-200.

[27] Djaouga, M., Arouna, O., Zakari, S., Ismaïla1, T.I. and Thomas, O. (2017) Cartographie des zones inondables dans les communes d'Abomey-Calavi, Seme-Podji et So-Ava au Bénin. Revue de Géographie de l'Université de Ouagadougou, 2, 58 p.

[28] Wang, H.G., Montoliu-Munoz, M., Guey, N.F.D. and the Geoville Group (2009) Préparation à la Gestion des Périls Naturels et des Risques liés aux Changement Climatique à Dakar, Sénégal. Une Approche Spatiale et Institutionnelle, Geoville Group et IAGU, rapport final, $96 \mathrm{p}$.

[29] Dhieb, M. and Salhi, B. (2010) Étude du réseau d'assainissement des eaux usées/pluviales dans la ville de Gafsa à l'aide d'un outil SIG. 18 p. 